\title{
Acute Intermittent Porphyria (AIP): A Mini-Review
}

\section{Moniruzzaman Ahmed*}

MAG Osmani Medical College, Bangladesh

Submission: March 06, 2017; Published: October 25, 2017

"Corresponding author: Moniruzzaman Ahmed, Associate Professor of Medicine, MAG Osmani Medical College, Abash 11/B, Sylmart Complex, East Zindabazar, Sylhet, Bangladesh, Tel:+8801715024714; Email: dr_zaman01217@yahoo.com

\section{Abstract}

Acute intermittent porphyria (AIP) is a rare autosomal dominant hereditary metabolic disorder having protean manifestations. A 15 year old girl admitted in the medicine department with the complaints of recurrent abdominal pain, convulsions and weakness of lower limbs was diagnosed as a case of AIP; the presence of porphyrins in urine confirmed the diagnosis of AIP. AIP can be life-threatening, so an accurate diagnosis and proper management are highly valuable.

Keywords: Acute Intermittent Porphyria (AIP); Abdominal pain; Neuropathy

\section{Discussion}

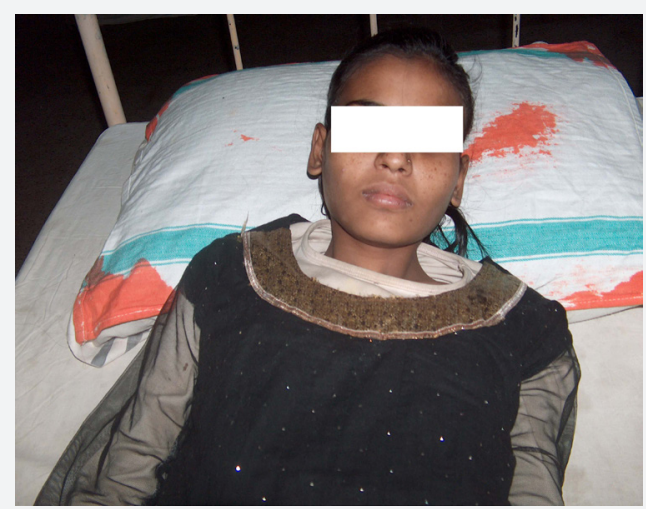

Figure 1: 15 year old girl of AIP.

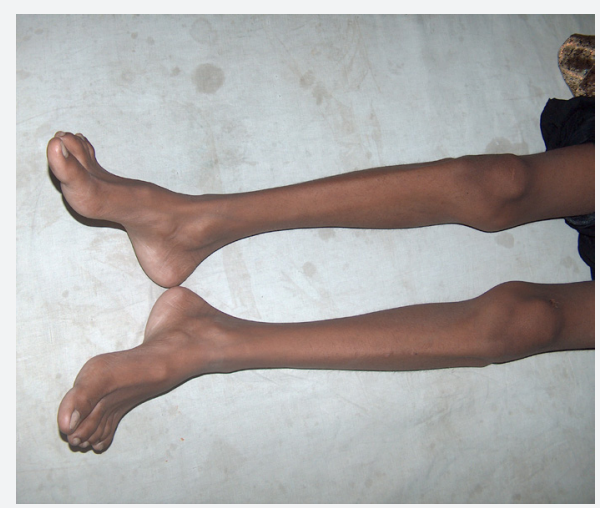

Figure 2: Motor neuropathy of lower limbs.
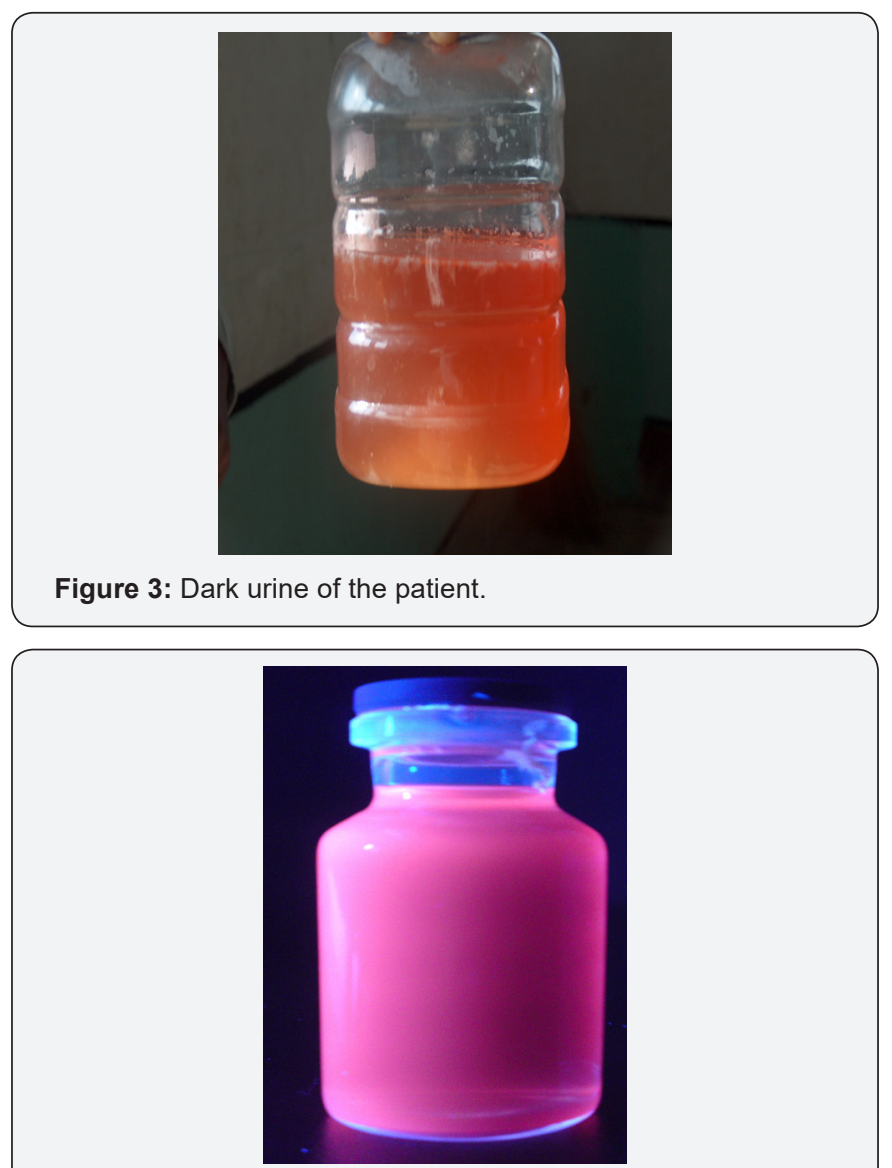

Figure 4: Red pink urine on Wood's light examination. 
A 15-year-old girl was hospitalized with the complaints of recurrent abdominal pain, convulsions and weakness of both lower limbs for about one year (Figure $1 \& 2$ ). She also complained of passage of urine that darkened on storage during the attack (Figure 3). She was admitted in different local clinics and treated as a case of conversion disorder or acute abdomen.

The clinical scenario and the presence of dark colored urine raised the suspicion of acute intermittent porphyria (AIP). The presence of excess porphyrin in the urine was detected by Wood's light examination. The dark urine turned red pink on exposure to Wood's light (Figure 4). The porphyrias are a group of rare metabolic disorders due to reduced metabolic activity of any of the enzymes in the heme iosynthetic pathway. The disorders may be either acquired or inherited due to a defective gene encoding the enzyme. The deficiency of any of the enzyme causes diverse clinical symptoms such as neurovisceral, cutaneous or mixed [1-3]. Porphyrins are intermediate products in the heme biosynthetic pathway. Heme is an essential component of both cellular hemoproteins produced mainly in the bone marrow which makes hemoglobin; in the liver the metabolizing enzymes cytochrome P450s are formed. The first step is the formation of $\delta$-aminolevulinic acid (ALA) from glycine and succinyl coenzyme A. The other steps are: 1) synthesis of a substituted pyrrole compound, porphobilinogen 2) condensation of 4 porphobilinogen molecules to yield porphyrinogen 3) modification of the side chain and ring and 4) introduction of iron to form heme. If no heme is present to inhibit the pathway, production of heme continues unopposed. Only protoporphyrin is used in heme synthesis. The other porphyrins have no physiologic function and must be excreted: proto and coproporphyrins in feces; uro and coproporphyrins in the urine and plasma $[4,5]$.

Acute intermittent porphyria (AIP), a rare autosomal dominant disorder is the most common type of porphyria that results from an approximately $50 \%$ deficiency of porphobilinogen (PBG) deaminase. The epidemiology of AIP is complicated because of its rarity and delay in diagnosis. The prevalence of AIP varies with a higher incidence in England, Ireland, and Scandinavia, the prevalence of AIP in the general adult population ranges between 1 \& 8 per lakh [6].
The clinical features of AIP may manifest at any age from puberty onwards but most commonly occur in the third decade of life; abdominal pain, peripheral neuropathy, and changes in mental status are the classic triad of an acute attack [7]. The clinical manifestations include neuropsychiatric symptoms and clinical signs (hysteria, anxiety, depression, phobias, agitation, psychosis, seizures and neuropathy), autonomic instability (hypertension, tachycardia, abdominal pain, nausea, vomiting, and constipation), dehydration and electrolytes imbalance (hyponatremia, hypokalemia, and hypocalcaemia) [2]. The peripheral neuropathy tends to be progressive and involves motor and sensory nerves. Muscular weakness may progress to quadriparesis, respiratory paralysis and arrest which may resemble Guillain-Barré syndrome [8]. The diagnosis of AIP depends on the clinical history and increased amounts of porphyrins or porphyrin precursors in the urine, feces and blood; the presence of reduced erythrocyte PBG deaminase activity helps to confirm the diagnosis. The Watson-Swartz is the most widely screening test and is approximately $95 \%$ sensitive and specific for PBGD but the test can not differentiate AIP from other porphyrin disorders. Molecular analysis is the 'gold standard'(100\% sensitive and specific) $[9,10]$. In the absence of sophisticated facilities, Wood's lamp examination could be an alternative diagnostic tool to detect the excess of porphyrins in the teeth, urine, stool samples, red blood cells and blister fluid in different forms of porphyrias. Addition of dilute hydrochloric acid to the sample being examined intensifies the fluorescence by converting porphyrinogens to porphyrins. Porphyrins appear intensely red when exposed to long-wave ultraviolet light (UV-A). This makes them visible with a Wood's lamp, and enables them to be measured accurately with a spectrofluorometer [11]. The patient's dark red urine turned red-pink in (Figure 4) Wood's light procedure.

Treatment strategies for AIP are focused on supportive and preventive measures. The precipitation of acute attacks of AIP can result from exogenous factors that increase the synthesis of microsomal cytochrome $\mathrm{P} 450$ in the liver such as barbiturates, exogenous sex hormones, sulfonamides, chloroquin, griseofulvin, diphenylhydantoin and many other drugs, acute infections, various phases of the menstrual cycle, fasting states, and overindulgence in alcohol [12].

Table 1: Therapy of acute attacks of porphyria [14].

\begin{tabular}{|r|}
\hline Remove inciting factors: alcohol, drugs, toxins, chemicals, smoking \\
\hline Nutritional supplementation: at least 300 grams glucose/day \\
\hline Frequent checks of neurologic status: especially watch for development of paresis of muscles of respiration \\
\hline Monitor for hypoventilation (rising arterial $\mathrm{pCO}_{2}$ ), hyponatremia or hypomagnesemia and treat vigorously if found \\
\hline Intravenous heme: $3-4 \mathrm{mg} / \mathrm{kg} /$ day for $3-5$ days \\
\hline Parenteral meperidine or morphine for pain \\
\hline Phenothiazines for nausea, vomiting, agitation, etc.
\end{tabular}


Seizures are treated by correction of hyponatremia. Many anticonvulsant drugs exacerbate acute porphyrias. Clonazepam may be less harmful than phenytoin, barbiturates or valproic acid. Bromides, gabapentin and vigabatin are safe [13]. Cimetidine is a cost-effective alternative to hemin for treating acute attacks, using $800 \mathrm{mg} /$ day until ALA levels are reduced to normal levels. Patients are advised to follow a well balanced diet with $60 \%$ to $70 \%$ of energy from carbohydrate. The therapy of acute attacks is given in Table 1 [14].

\section{Conclusion}

Diagnosis of AIP should be based on high degree of clinical awareness. The constellation of diverse symptoms involving multiple systems makes the diagnosis difficult. AIP is a life threatening disease, so correct diagnosis, proper management strategies regarding abortive and preventive therapies, treatment of acute crisis and to focus on preventing chronic complications are crucial to save the life of the patient. The patient or the guardians should be referred to genetic specialists for family screening and counseling.

\section{Acknowledgement}

Dr. Rezwana Chowdhury, postgraduate trainee of Medicine, indoor medical officer in Sylhet MAG Osmani Medical College in helping to prepare the script.

\section{Conflicts of Interest}

The author has no conflicts of interest of any kind.

\section{References}

1. Thadani H, Deacon A, Peters T (2000) Diagnosis and management of Porphyria. BMJ 320(7250): 1647-1651.

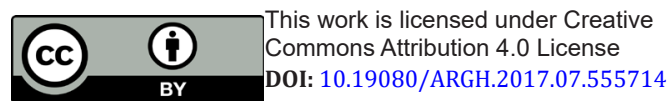

2. Elder GH, Hift RJ, Meissner PN (1997) The acute porphyrias. The Lancet 349: 1613-1617.

3. González Arriaza HL, Bostwick JM (2003) Acute Porphyrias: A Case Report and Review. Am J Psychiatry 160(3): 450-458.

4. Abel G, Palmer Toy D (2002) Heme synthesis and catabolism. In: McClatchey KD (Eds.), Clinical Laboratory Medicine. (2 ${ }^{\text {nd }}$ edn), Lippincott Williams \& Wilkins, USA, pp. 407-417.

5. Kappas A, Sassa S, Galbraith RA, Nordmann Y (1997) The porphyrias. In: Scriver CR, Beaudet AL, Sly WS, Walle D, (Eds.), The metabolic and molecular basis of inherited disease. ( $7^{\text {th }}$ edn), McGraw-Hill, USA, pp. 2103-2159.

6. Ackner B, Cooper JE, Gray CH, Kelly M (1962) Acute porphyria: a neuropsychiatric and biochemical study. Journal of Psychosomatic Research 6(1): 1-24.

7. Regan L, Gonslaves L, Tesar G (1999) Acute intermittent porphyria. Psychosomatics 40(6): 521-523.

8. Tefferi A, Colgan JP, Solberg LA (1994) Acute porphyrias: diagnosis and management. Mayo Clin Proc 69(10): 991-995.

9. Elder GH, Smith SG, Smyth SJ (1990) Laboratory investigation of the porphyrias. Ann Clin Biochem 27: 395-412.

10. Palmer KM (2006) Abdominal Pain due to Acute Intermittent Porphyria: When is the Sound of Hoof-Beats not Horses, but Zebras? A Case Report. Dimens Crit Care Nurs 25(3): 103-109.

11. Halprin KM (1967) Diagnosis with Wood's light: The porphyrias. JAMA 200(6): 460.

12. (2017) American Porphyria Foundation.

13. Ahmed M, Ahmed MS, Patwary MI, Miah MT, Hasan MK, et al. (2015) Mymensingh Med J 24(2): 420-423.

14. Cojocaru IM, Sapira V, Socoliuc G, Hertera C, Balea M, et al. (2012) Acute intermittent porphyria diagnostic and treatment traps. Rom J Intern Med 50(1): 33-41.

\section{Your next submission with JuniperPublishers will reach you the below assets}

- Quality Editorial service

- Swift Peer Review

- Reprints availability

- E-prints Service

- Manuscript Podcast for convenient understanding

- Global attainment for your research

- Manuscript accessibility in different formats

( Pdf, E-pub, Full Text, audio)

- Unceasing customer service

Track the below URL for one-step submission https://juniperpublishers.com/online-submission.php 